\title{
Variations of forest soil organic carbon and its influencing factors in east China
}

\author{
Yan $\mathrm{Liu}^{1} \cdot \operatorname{Suyan} \mathrm{Li}^{1} \cdot \mathrm{Xiangyang} \mathrm{Sun}^{1} \cdot \mathrm{Xin}^{\mathrm{Yu}}{ }^{1}$
}

Received: 29 September 2015 / Accepted: 27 January 2016/Published online: 8 February 2016

(C) INRA and Springer-Verlag France 2016

\begin{abstract}
- Key message Forest and soil types are the main factors that influence the distribution pattern of soil organic carbon (SOC) in forests across east China. In general, SOC density was largest in north-eastern China, followed by south-eastern China, and lowest in middle-eastern China, due to regional climate and the dominant forest type (young plantations in middle-eastern China).

- Context Forest SOC plays an important role in the carbon cycle in China, but large spatial heterogeneity and insufficient field observations lead to large uncertainties in the estimation of SOC.

- Aims The objectives of this study were to evaluate forest SOC density in different geographic regions, forest types, and soil types and to investigate the spatial variation of SOC in forests across east China.
\end{abstract}

\section{Handling Editor: Gilbert Aussenac}

Contribution of the co-authors Yan Liu: collaboratively designing the work, measuring the samples, running data analysis, and editing the manuscript

Suyan Li: collaboratively designing and supervising the work Xiangyang Sun: collaboratively designing the work and discussing the manuscript

Xin Yu: collecting the samples and reviewing the manuscript

Electronic supplementary material The online version of this article (doi:10.1007/s13595-016-0543-8) contains supplementary material, which is available to authorized users.

Suyan Li

lisuyan@bjfu.edu.cn

1 College of Forestry, Beijing Forestry University, Beijing 100083, China
- Methods The estimation of forest SOC was based on 348 soil profiles, which were collected from 116 forest sites in east China during 2008-2011.

- Results The average SOC content was $17.5 \mathrm{~g} \mathrm{C} \mathrm{kg}^{-1}$, which leads to an average SOC density of $12.4 \mathrm{~kg} \mathrm{C} \mathrm{m}^{-2}$. The average SOC density in the organic horizon and mineral horizon was 5.47 and $6.91 \mathrm{~kg} \mathrm{C} \mathrm{m}^{-2}$, respectively, with $44.2 \% \mathrm{SOC}$ density dominating in the organic horizon. The average forest SOC density in north-eastern, middle-eastern, and southeastern China was $13.5,9.95$, and $13.3 \mathrm{~kg} \mathrm{C} \mathrm{m}^{-2}$, respectively. - Conclusion SOC distribution varied among regions, forest types, and soil types in east China. The importance of influencing factors switched with depth, precipitation, and temperature dominating in the organic horizon and soil texture dominating in the mineral horizon.

Keywords East China $\cdot$ Forest $\cdot$ Soil $\cdot$ Soil organic carbon

\section{Introduction}

Soil organic carbon (SOC) stored in forest soils comprises about $73 \%$ of global soil carbon storage (Sedjo 1993). In temperate forest ecosystems, the carbon pool in forest soil is approximately twice as large as the pool in forest vegetation (Malhi et al. 1999). SOC is an important component in forest soils and ecosystems. SOC accumulation and decomposition rates have direct effects on terrestrial ecosystem carbon storage and the global carbon balance. SOC is also essential for improving soil quality and hence sustains forest production. Thus, understanding SOC distribution in forest ecosystems is critical.

As of 2014 , forest coverage (208 million ha) is approximately $22 \%$ in China. Additionally, plantation forests in China cover more land than those in any other countries of the world (Winjum and Schroeder 1997). China's forests are 
mainly distributed in the humid and sub-humid eastern regions. Forest resources in east China account for $71 \%$ of national forest area, and growing stock accounts for $67 \%$ of the country (The State Forest Bureau 2014). During the past several decades, large amounts of research programs on forest soil carbon cycling have been conducted at different scales in mountainous or other regions (Huang et al. 2013; Li et al. 2013; Liu et al. 2012; Zhang et al. 2011). However, these studies have usually examined carbon stocks and their dynamics for specific forest types or for single ecosystem components. In addition, previous estimates have been mainly based on China's first and second soil survey data, which limits our understanding of the current carbon stock and its distribution in forest soil. Consequently, regional- or national-scale assessments of the forest carbon balance are still lacking, and estimating carbon cycling is difficult because of the extremely complex topography, vegetations, stand age, and climate as well as natural soil variability (Bohn 1982; Batjes 1996; Eswaran et al. 1993; Kern 1994; Post et al. 1985, 1990; Pregitzer and Euskirchen 2004), and a lack of extensive soil data collection from the field. Therefore, estimation of forest soil carbon stock and allocation play an important role in predicting future climate change and forest management.

East China is one of China's major areas of forests. The forest ecosystems in east China vary from cold-temperate coniferous forests in the north-eastern provinces to temperate needle broad-leaved mixed forests, then warm temperate deciduous broad-leaved forests to subtropical evergreen broad-leaved forests to tropical monsoon forests in the south according to the climatic zones (Hou 1983). This study, based on geographical regionalization and forest district, defines east China in a very broad sense while north-eastern, middle-eastern, and south-eastern China are defined more narrowly. Field data were collected from 116 sites to estimate the forest SOC density and to analyze how various factors affected the distribution of forest SOC in east China. The objectives of this study are (1) to explore the distribution pattern of forest SOC and evaluate the density of SOC in different geographic regions, forest types, and soil types in east China and (2) to analyze the relationship between SOC density and climate-related factors (mean annual temperature (MAT), mean annual precipitation (MAP), soil-related factors (soil nitrogen, bulk density, soil texture, and $\mathrm{pH}$ ), and position-related factors (longitude, latitude, and elevation)) in forests across east China.

\section{Materials and methods}

\subsection{Study area}

The study area is located in the eastern monsoon region of China, one of China's major forest regions. Three geographic regions were selected representing the main forest types and soil types in a very broad sense, specifically, north-eastern China, middle-eastern China, and south-eastern China (Table 1).

Three hundred forty-eight soil profiles were from 116 sites (three soil profiles at each site) in forests of east China during 2008-2011 (Fig. 1). Detailed information of these study sites is shown in Appendix 1. In this study, based on the investigation and data collection from China's second national soil survey (Chinese National Investigation Office 1993-1996; Chinese Soil Taxonomy Research Group, Institute of Soil Science, Chinese Academy of Sciences, Cooperative Research Group on Chinese Soil Taxonomy 2001), Chinese forest inventory (Chinese Ministry of Forestry 2009; Zhang 1986), and published literature, the study sites was selected mainly based on the distribution of soil and forest types and terrain. A total of 116 sites were surveyed in the three main forest regions: 40 sites in north-eastern China, 34 sites in middle-eastern China, and 42 sites in south-eastern China. The study sites covered all major climate zones, forest types, and soil types across east China.

\subsection{Sampling method}

Each soil profile was divided pedogenetically into three major horizons, A, B, and C horizons (National Soil Survey Office 1998). For each soil pit, soil samples were collected from each horizon. Soil profile data included extensive information on soil type (using Genetic Soil Classification of China, Chinese Soil

Table 1 Site characteristics for east China on a broad scale, including north-eastern China, middle-eastern China, and south-eastern China

\begin{tabular}{|c|c|c|c|c|c|}
\hline Geographic region & Climatic zone & Vegetation zone & $\begin{array}{l}\text { Main soil type } \\
\text { (Genetic Soil Classification of China) }\end{array}$ & $\operatorname{MAT}\left({ }^{\circ} \mathrm{C}\right)$ & $\operatorname{MAP}(\mathrm{mm})$ \\
\hline North-eastern China & $\begin{array}{l}\text { Cold-temperate zone } \\
\text { Temperate zone }\end{array}$ & $\begin{array}{l}\text { Cold-temperate coniferous forests } \\
\text { Temperate needle broad-leaved mixed forests }\end{array}$ & $\begin{array}{l}\text { Brown coniferous forest soils } \\
\text { Dark-brown earths }\end{array}$ & -6 to 7 & 500 to 800 \\
\hline Middle-eastern China & Warm temperate zone & Warm temperate deciduous broad-leaved forests & Brown earths; cinnamon soils & 8 to 14 & 400 to 800 \\
\hline South-eastern China & $\begin{array}{l}\text { Subtropical zone } \\
\text { Tropical zone }\end{array}$ & $\begin{array}{l}\text { Subtropical evergreen broad-leaved forests } \\
\text { Tropical monsoon forests }\end{array}$ & $\begin{array}{l}\text { Yellow-brown soil; red earths; } \\
\text { yellow earths; lateritic red earths } \\
\text { Latosols }\end{array}$ & 16 to 28 & 800 to 2600 \\
\hline
\end{tabular}

MAT mean annual temperature, MAP mean annual precipitation 


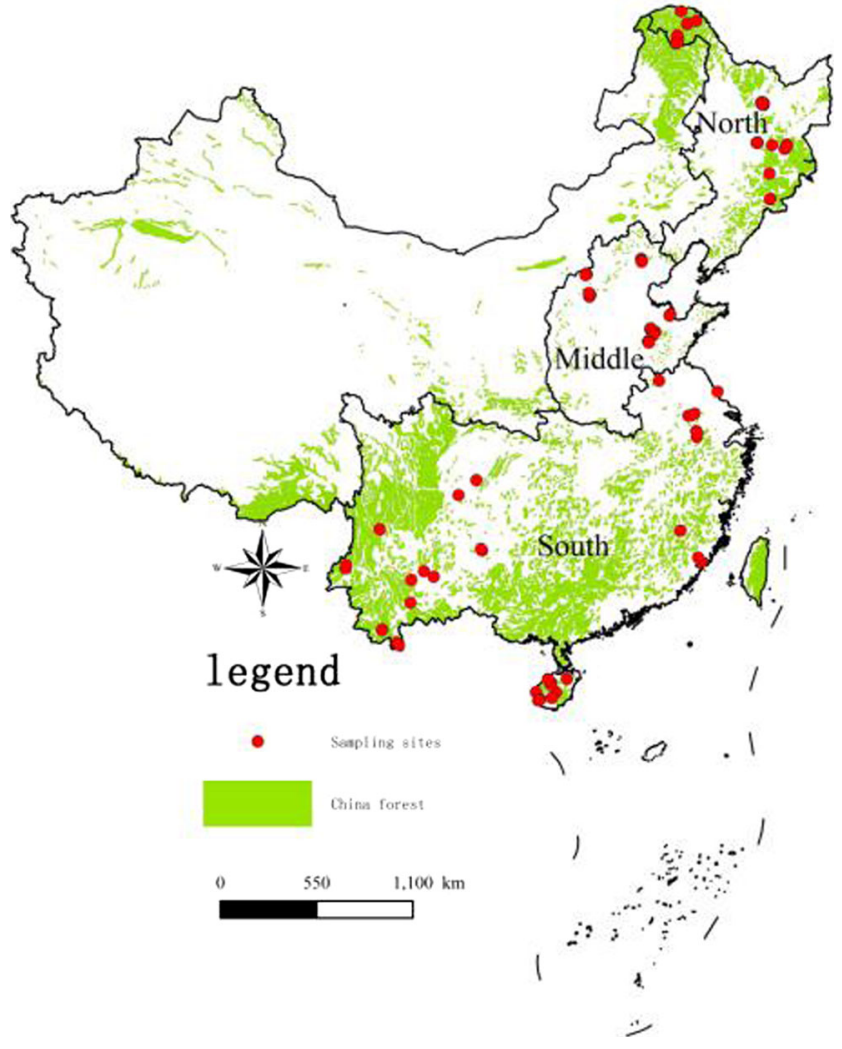

Fig. 1 Map showing the distribution of forest soil sites used in this study of east China. North north-eastern China, Middle middle-eastern China, and South south-eastern China

General Survey Office 1993), profile location, elevation, vegetation, bulk density, horizon depth, and organic carbon, along with other physicochemical properties. Major physicochemical properties of the 348 soil profiles are shown in Table 2. Soil bulk density samples were collected from each horizon using a cutting ring (volume of $100 \mathrm{~cm}^{3}$ ). All samples were collected between June 2008 and October 2011. All the soil samples were air dried in the laboratory and passed through a 2-mm sieve to remove coarse roots and easily detectable plant litter prior to laboratory analysis. SOC content was analyzed using the dichromate oxidation (external heat applied) method (Nelson and Sommers 1975). Bulk density was determined by drying the core samples at $105{ }^{\circ} \mathrm{C}$ until constant weight. Particle-size distribution was analyzed by pipette method (ISRIC 1995). Soil $\mathrm{pH}$ was determined by $\mathrm{pH}$ meter using a ratio of soil to distilled water of 1:2.5. Soil total nitrogen (TN) was measured according to the Kjeldahl method (Parkinson and Allen 1975).

\subsection{Climate data}

Mean annual temperature and precipitation data were obtained from China Meteorological Data Sharing Service System (China Meteorological Administration).

\subsection{Calculation of SOC density}

SOC density $\left(\mathrm{kg} \mathrm{C} \mathrm{m}^{-2}\right)$ refers to the organic carbon storage per unit area $\left(1 \mathrm{~m}^{2}\right)$ at a certain depth; it is the main basis for estimating SOC storage (Jin et al. 2001; Yang et al. 2011; Dai et al. 2014). In this study, for better comparison among data sets, soil profiles were divided into organic (A) horizon and mineral (B and $\mathrm{C}$ ) horizon, with carbon content and density calculated separately. Carbon content and density in the entire soil profile were then calculated as follows.

SOC content was calculated according to Eq. 1:

SOC content $=\frac{\sum_{i=1}^{n} T_{i} \times C_{i} \times\left(1-G_{i}\right)}{\sum_{i=1}^{n} T_{i}}$

SOC density was calculated according to Eq. 2 :

$\mathrm{SOC}_{\text {density }}=\sum_{i=1}^{n} T_{i} \times p_{i} \times C_{i} \times\left(1-G_{i}\right) / 100$

where $\mathrm{SOC}_{\text {content }}$ is the SOC content of the target depth of the soil $\left(\mathrm{g} \mathrm{C} \mathrm{kg}^{-1}\right), n$ is the number of soil horizons of the profile, $T_{i}(\mathrm{~cm})$ is the thickness of horizon $i, C_{i}\left(\mathrm{~g} \mathrm{C} \mathrm{kg}^{-1}\right)$ is the organic carbon concentration of horizon $i$, and $G_{i}$ (dimensionless) is the mass percentage of rock fragment content $\left(>2 \mathrm{~mm}\right.$ ) of horizon $i$. $\mathrm{SOC}_{\text {density }}$ is the SOC density of the target depth of the soil $\left(\mathrm{kg} \mathrm{C} \mathrm{m}^{-2}\right)$ and $p_{i}\left(\mathrm{~g} \mathrm{~cm}^{-3}\right)$ is the soil bulk density of horizon $i$.

Table 2 Effective soil depth, SOC content, total N, C/N ratio, bulk density, $\mathrm{pH}$, clay content, silt content, and sand content of each study area in east China

\begin{tabular}{|c|c|c|c|c|c|c|c|c|c|}
\hline $\begin{array}{l}\text { Geographic } \\
\text { region }\end{array}$ & $\begin{array}{l}\text { Effective soil } \\
\text { depth }(\mathrm{cm})\end{array}$ & $\begin{array}{l}\text { SOC content } \\
\left(\mathrm{g} \mathrm{C} \mathrm{kg}^{-1}\right)\end{array}$ & $\begin{array}{l}\text { Total N } \\
\left(\mathrm{g} \mathrm{kg}^{-1}\right)\end{array}$ & $\mathrm{C} / \mathrm{N}$ ratio & $\begin{array}{l}\text { Bulk density } \\
\left(\mathrm{g} \mathrm{cm}^{-3}\right)\end{array}$ & $\mathrm{pH}$ & $\begin{array}{l}\text { Clay content } \\
\left(\mathrm{g} \mathrm{kg}^{-1}\right)\end{array}$ & $\begin{array}{l}\text { Silt content } \\
\left(\mathrm{g} \mathrm{kg}^{-1}\right)\end{array}$ & $\begin{array}{l}\text { Sand content } \\
\left(\mathrm{g} \mathrm{kg}^{-1}\right)\end{array}$ \\
\hline North-eastern China & $78 \pm 23$ & $20.9 \pm 38.3$ & $1.99 \pm 3.66$ & $13.3 \pm 14.8$ & $1.29 \pm 0.31$ & $5.4 \pm 0.6$ & $528 \pm 167$ & $268 \pm 64$ & $204 \pm 119$ \\
\hline Middle-eastern China & $82 \pm 26$ & $12.2 \pm 11.7$ & $0.82 \pm 0.98$ & $17.9 \pm 8.45$ & $1.32 \pm 0.19$ & $7.5 \pm 0.8$ & $513 \pm 157$ & $304 \pm 100$ & $183 \pm 111$ \\
\hline South-eastern China & $84 \pm 30$ & $19.3 \pm 26.8$ & $0.97 \pm 1.63$ & $20.2 \pm 7.98$ & $1.28 \pm 0.19$ & $6.2 \pm 0.7$ & $444 \pm 95$ & $254 \pm 123$ & $302 \pm 95$ \\
\hline Total region & $82 \pm 27$ & $17.5 \pm 25.5$ & $1.28 \pm 2.04$ & $16.4 \pm 8.73$ & $1.26 \pm 0.24$ & $6.3 \pm 1.2$ & $493 \pm 165$ & $274 \pm 89$ & $233 \pm 129$ \\
\hline
\end{tabular}

Mean \pm standard deviation 


\subsection{Statistical analysis}

One-way ANOVA and $t$ test were conducted to evaluate whether the vertical distribution of SOC differed significantly among various study regions and soil horizons. Means of the main effects were compared by Duncan test. Pearson correlation analysis was conducted to determine the relationships between SOC density and climate-related factors (MAP, MAT), soil-related factors (nitrogen, $\mathrm{pH}$, bulk density, and soil texture), and position-related factors (longitude, latitude, and elevation). Statistical analyses were performed by SPSS 16.0 program.

\section{Results}

\subsection{The vertical and spatial distribution of SOC}

In all forest soils, the bulk density of soil increased with increasing soil depth (Fig. 2). In east China, the average forest soil bulk density and SOC content in the entire soil profile were $1.28 \mathrm{~g} \mathrm{~cm}^{-3}$ and $17.5 \mathrm{~g} \mathrm{C} \mathrm{kg}^{-1}$ (Table 3). Soil bulk density in the mineral horizon was higher than that in the organic horizon among all the sites. Approximately $51.7 \%$ of the study sites had SOC content in the range of 0 $10.00 \mathrm{~g} \mathrm{C} \mathrm{kg}^{-1}$, while only about $9.48 \%$ of the study sites had SOC content more than $40 \mathrm{~g} \mathrm{C} \mathrm{kg}^{-1}$.
This study spanned across $18^{\circ} \mathrm{N}-53^{\circ} \mathrm{N}$; the forest SOC density in study sites varied considerably in east China (Fig. 3). The SOC density in the entire soil profile ranged from 0.80 to $51.4 \mathrm{~kg} \mathrm{C} \mathrm{m}^{-2}$; the average density was $12.4 \mathrm{~kg} \mathrm{C} \mathrm{m}^{-2}$. The SOC density in the organic horizon ranged from 0.16 to $33.9 \mathrm{~kg} \mathrm{C} \mathrm{m}^{-2}$, and the average content was $5.47 \mathrm{~kg} \mathrm{C} \mathrm{m}^{-2}$. The SOC density in the mineral horizon range varied from 0.50 to $34.8 \mathrm{~kg} \mathrm{C} \mathrm{m}^{-2}$; the average density was $6.91 \mathrm{~kg} \mathrm{C} \mathrm{m}^{-2}$ (Fig. 4). The average SOC density in the organic horizon was approximately $44.2 \%$ of the total organic carbon density in the soil profile.

\subsection{SOC among different geographic regions}

The soil bulk density in the north-eastern, middle-eastern, and south-eastern China ranged from 0.06 to $1.93,0.75$ to 1.91 , and 0.60 to $1.75 \mathrm{~g} \mathrm{~cm}^{-3}$, respectively (Table 3 ). The average soil bulk density was $1.29,1.24$, and $1.32 \mathrm{~g} \mathrm{~cm}^{-3}$, respectively, and the average soil depth was 78,82 , and $84 \mathrm{~cm}$, respectively, in the entire soil profile for the three study regions (north-eastern, middle-eastern, and south-eastern China).

SOC content decreased with increasing soil depths in all regions. SOC content ranged from 0.638 to $214,0.292$ to 91.4 , and 0.266 to $89.4 \mathrm{~g} \mathrm{C} \mathrm{kg}^{-1}$, in north-eastern, middle-eastern, and south-eastern China regions, respectively. The average SOC content in the entire soil profile for the three study
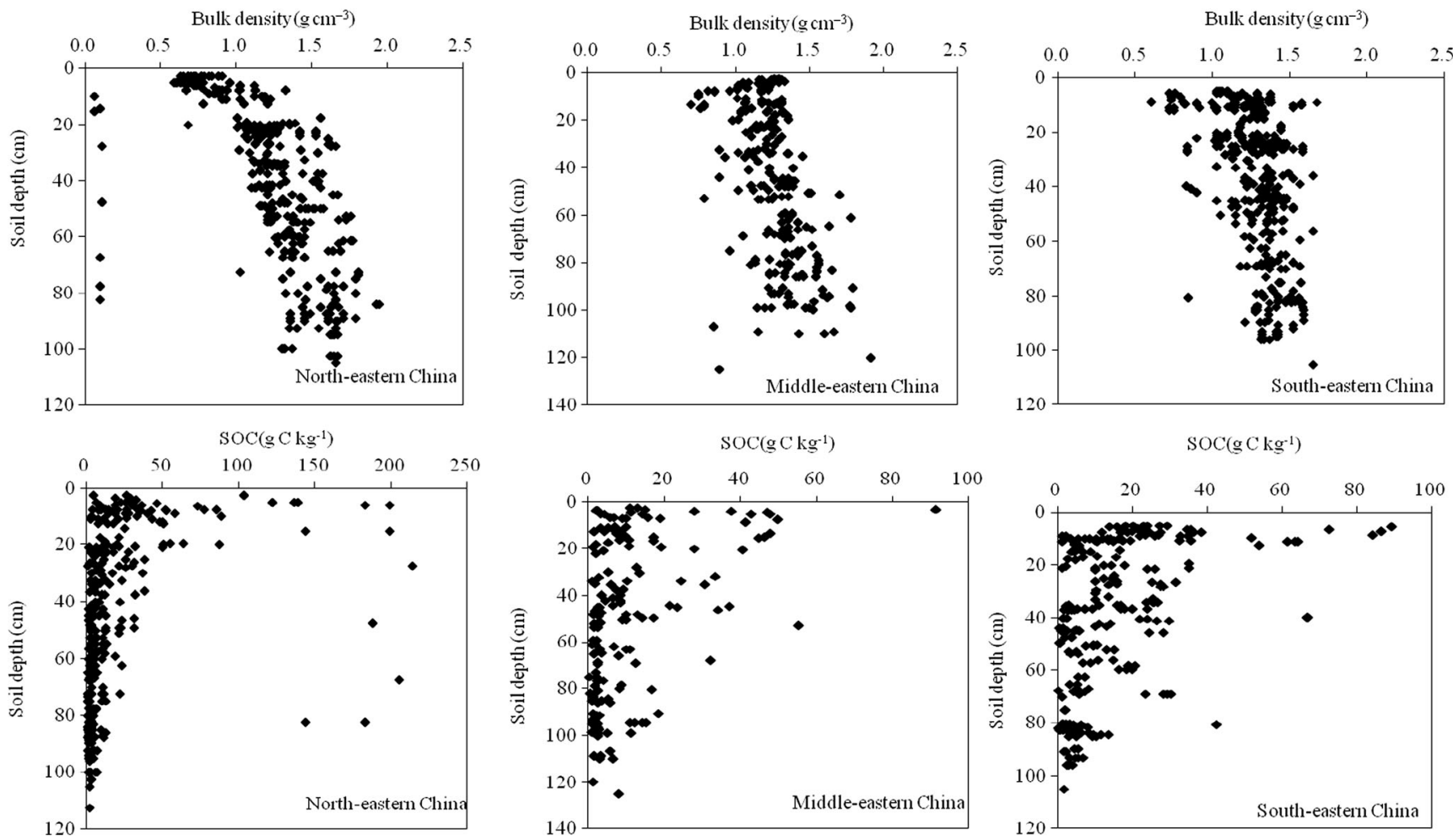

Fig. 2 Distribution of bulk density and organic carbon in forest soil profiles 
Table 3 The comparison of SOC content and bulk density in east China on a broad scale, including north-eastern China, middleeastern China, and south-eastern China

\begin{tabular}{lllll}
\hline Geographic region & Soil layer & Thickness $(\mathrm{cm})$ & $D_{\mathrm{b}}\left(\mathrm{g} \mathrm{cm}^{-3}\right)$ & SOC $\left(\mathrm{g} \mathrm{C} \mathrm{kg}^{-1}\right)$ \\
\hline North-eastern China & Organic horizon & $25 \pm 15$ & $0.88 \pm 0.25 \mathrm{Ab}$ & $50.6 \pm 54.4 \mathrm{Aa}$ \\
& Mineral horizon & $53 \pm 25$ & $1.40 \pm 0.33 \mathrm{Aa}$ & $15.5 \pm 40.3 \mathrm{Ba}$ \\
& Profile & $78 \pm 23$ & $1.29 \pm 0.31 \mathrm{a}$ & $20.9 \pm 38.3 \mathrm{a}$ \\
Middle-eastern China & Organic horizon & $28 \pm 21$ & $1.12 \pm 0.16 \mathrm{Aa}$ & $20.4 \pm 20.8 \mathrm{Ab}$ \\
& Mineral horizon & $57 \pm 28$ & $1.31 \pm 0.42 \mathrm{Aa}$ & $7.44 \pm 9.43 \mathrm{Bb}$ \\
& Profile & $82 \pm 26$ & $1.24 \pm 0.19 \mathrm{a}$ & $12.2 \pm 11.7 \mathrm{~b}$ \\
South-eastern China & Organic horizon & $20 \pm 7$ & $1.16 \pm 0.22 \mathrm{Aa}$ & $27.7 \pm 26.5 \mathrm{Ab}$ \\
& Mineral horizon & $65 \pm 28$ & $1.32 \pm 0.20 \mathrm{Aa}$ & $16.2 \pm 31.8 \mathrm{Aa}$ \\
& Profile & $84 \pm 30$ & $1.28 \pm 0.19 \mathrm{a}$ & $19.3 \pm 26.8 \mathrm{a}$ \\
Total region & Organic horizon & $23 \pm 15$ & $1.06 \pm 0.25 \mathrm{~A}$ & $33.5 \pm 23.5 \mathrm{~A}$ \\
& Mineral horizon & $58 \pm 27$ & $1.35 \pm 0.32 \mathrm{~A}$ & $13.5 \pm 25.7 \mathrm{~B}$ \\
& Profile & $82 \pm 27$ & $1.26 \pm 0.24$ & $17.5 \pm 25.5$ \\
\hline
\end{tabular}

Mean \pm standard deviation. Different lowercase letters within columns indicate significant differences among different regions for each soil horizon. Different uppercase letters within columns indicate significant differences among the different soil horizons in each region

$D_{b}$ bulk density regions was $20.9,12.2$, and $19.3 \mathrm{~g} \mathrm{C} \mathrm{kg}^{-1}$, respectively. The forest SOC content was highest in north-eastern China, intermediate in south-eastern China, and lowest in middle-eastern China.

The SOC density in the organic horizon, mineral horizon, and entire soil profile throughout three study regions ranged from 0.49 to $23.8,0.94$ to 34.7 , and 1.43 to $51.4 \mathrm{~kg} \mathrm{C} \mathrm{m}^{-2}$ (north-eastern China); 0.16 to 33.9, 0.67 to 29.1 , and 2.09 to $35.7 \mathrm{~kg} \mathrm{C} \mathrm{m}^{-2}$ (middle-eastern China); and 0.30 to $18.0,0.50$ to 33.6 , and 0.80 to $44.3 \mathrm{~kg} \mathrm{C} \mathrm{m}^{-2}$ (south-eastern China), respectively. The average SOC density in the entire soil profile for north-eastern, middle-eastern, and south-eastern China was $13.5,9.95$, and $13.3 \mathrm{~kg} \mathrm{C} \mathrm{m}^{-2}$, respectively (Fig. 4). The SOC density in the organic horizon was highest in

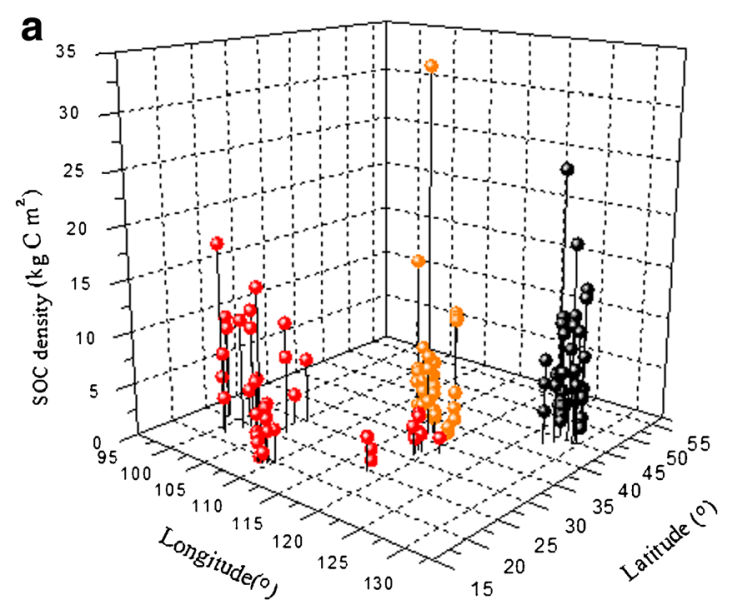

Fig. 3 Forest soil site data for organic horizons (A horizon) SOC density $\left(\mathrm{kg} \mathrm{C} \mathrm{m}^{-2}\right)(\mathbf{a})$ and the soil profiles' SOC density $\left(\mathrm{kg} \mathrm{C} \mathrm{m}^{-2}\right)(\mathbf{b})$, in relation to longitude and latitude for the site. Site data are shown in north-eastern China, followed by south-eastern China, and lowest in middle-eastern China. The SOC density in the organic horizon accounted for 46.1, 52.7, and $37.1 \%$ of the total SOC density in north-eastern, middle-eastern, and southeastern China, respectively. The SOC density for the entire soil profile was highest in north-eastern China, intermediate in south-eastern China, and lowest in middle-eastern China.

\subsection{SOC among different forest types}

The average content of SOC ranged from 12.2 to $33.3 \mathrm{~g} \mathrm{C} \mathrm{kg}^{-1}$, and there was a significant difference among the five forest types with the highest in the coldtemperate coniferous forests, followed by subtropical

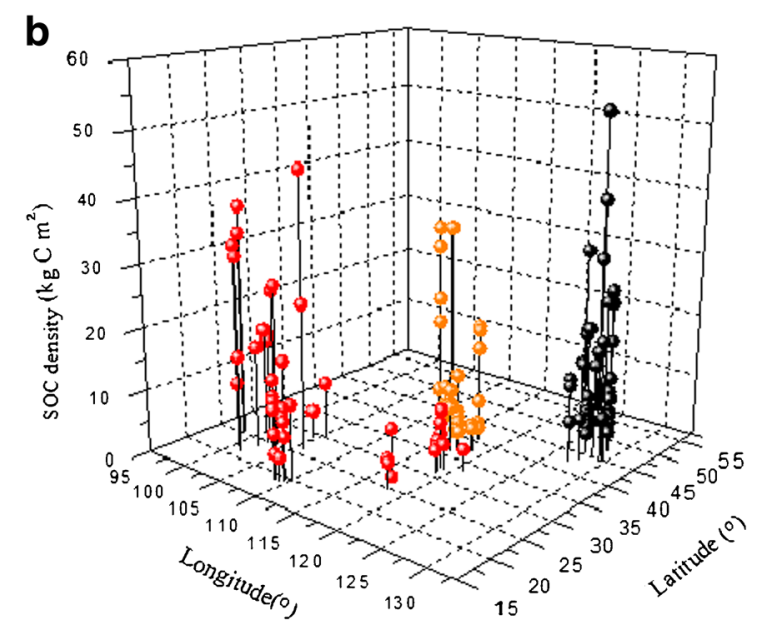

relation to their distribution among north-eastern China (black), middleeastern China (orange), and south-eastern China (red) 
a

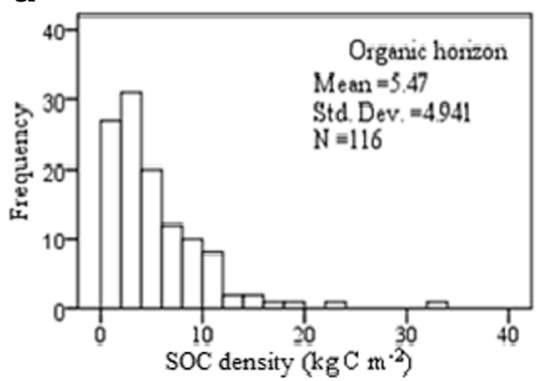

d

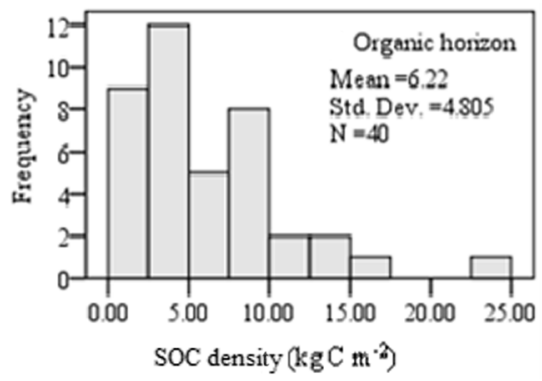

g
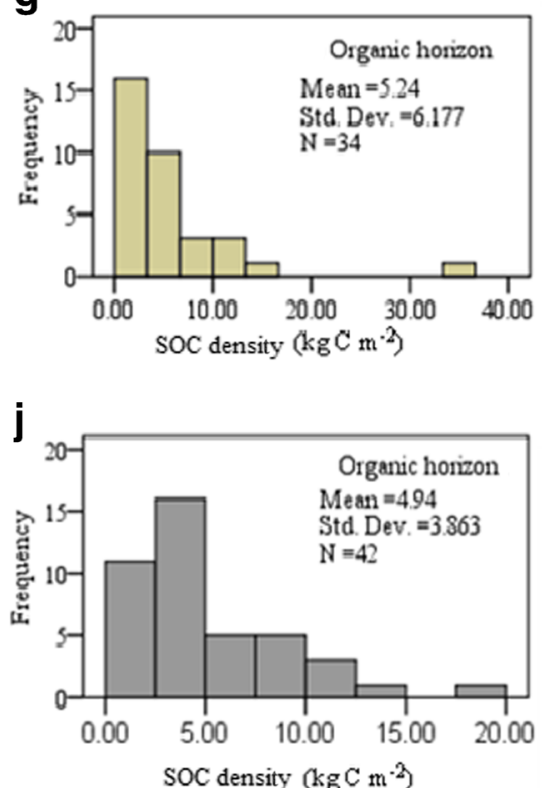

b

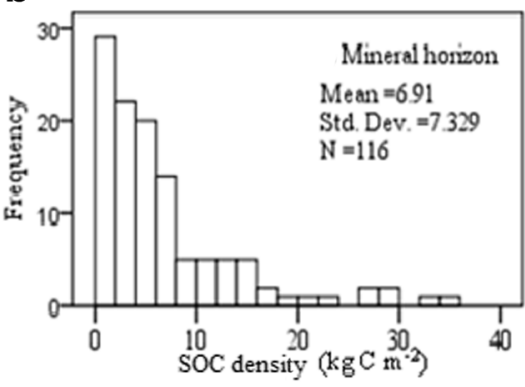

e

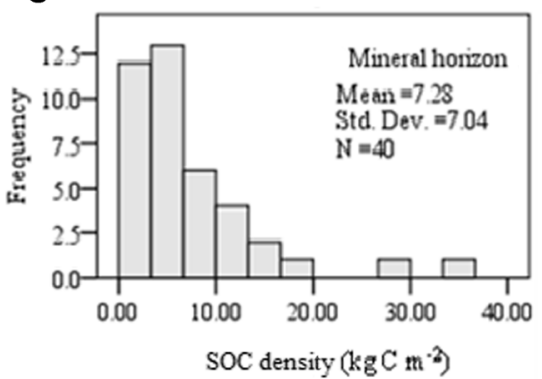

h

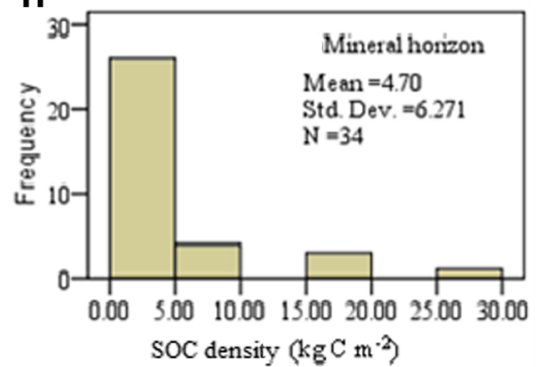

k

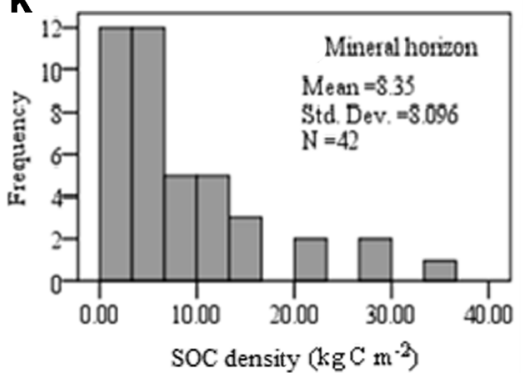

C

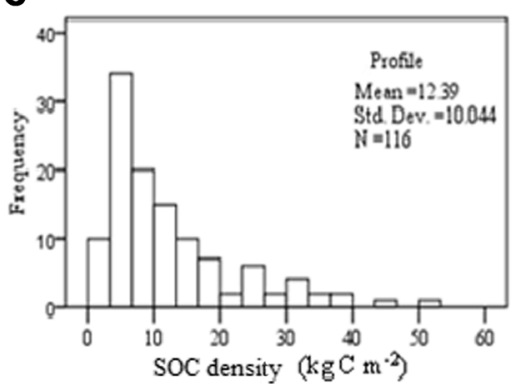

f

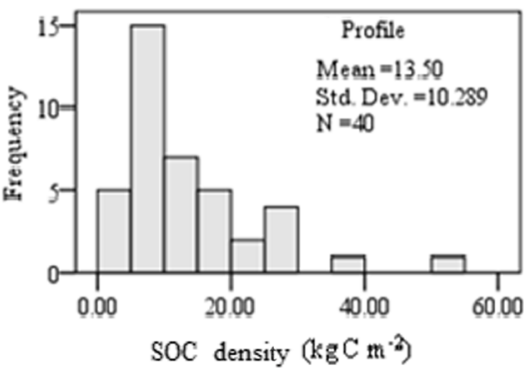

i

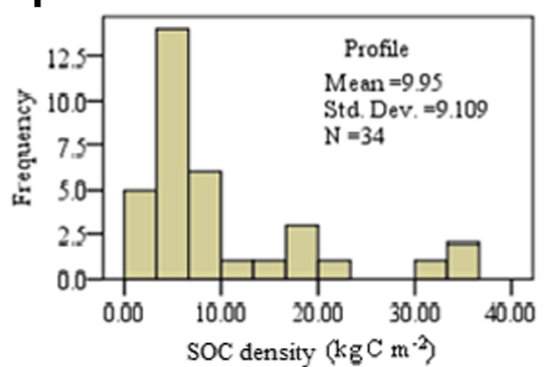

I

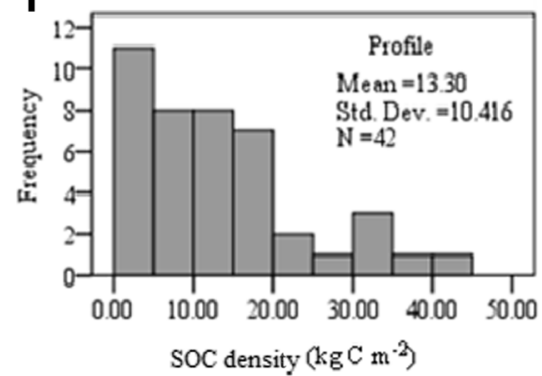

Fig. 4 Frequency distribution of SOC density in forest soils in east China at different layers (organic horizons, mineral horizons, and soil profiles). a-c Total region; $\mathbf{d}-\mathbf{f}$ north-eastern China; $\mathbf{g}-\mathbf{i}$ middle-eastern China; $\mathbf{j}-\mathbf{I}$ south-eastern China

evergreen broad-leaved forests, temperate needle broadleaved mixed forests, tropical monsoon forests, and the lowest in the warm temperate deciduous broad-leaved forests (Table 4). The average SOC density ranged from 9.95 to $19.8 \mathrm{~kg} \mathrm{C} \mathrm{m}^{-2}$ among five forest types. SOC density was highest in the cold-temperate coniferous forests than the other four forest types, and the lowest was observed in the warm temperate deciduous broad-leaved forests.

\subsection{SOC content and density among different soil types}

Organic carbon content and density showed a significant difference among 22 Genetic Soil Classification of China soil groups in east China due to the high spatial variability (Table 5). SOC density ranged from 1.43 to $35.0 \mathrm{~kg} \mathrm{C} \mathrm{m}^{-2}$ in the entire soil profiles, 0.49 to $13.7 \mathrm{~kg} \mathrm{C} \mathrm{m}^{-2}$ in the organic horizon, and 0.94 to 
Table 4 SOC content and density in the different forest types in east China

\begin{tabular}{|c|c|c|c|c|c|c|c|}
\hline \multirow[t]{2}{*}{ Forest type } & \multirow{2}{*}{$\begin{array}{l}\text { Number } \\
\text { of profiles }\end{array}$} & \multicolumn{3}{|c|}{ SOC content $\left(\mathrm{g} \mathrm{C} \mathrm{kg}^{-1}\right)$} & \multicolumn{3}{|c|}{ SOC density $\left(\mathrm{kg} \mathrm{C} \mathrm{m}{ }^{-2}\right)$} \\
\hline & & $\begin{array}{l}\text { Organic } \\
\text { horizon }\end{array}$ & $\begin{array}{l}\text { Mineral } \\
\text { horizon }\end{array}$ & Profile & $\begin{array}{l}\text { Organic } \\
\text { horizon }\end{array}$ & $\begin{array}{l}\text { Mineral } \\
\text { horizon }\end{array}$ & Profile \\
\hline Cold-temperate coniferous forests & 36 & $104 \pm 61.8 \mathrm{~A}$ & $22.3 \pm 46.0 \mathrm{~A}$ & $33.3 \pm 47.0 \mathrm{~A}$ & $8.19 \pm 6.67 \mathrm{~A}$ & $11.6 \pm 10.4 \mathrm{~A}$ & $19.8 \pm 14.2 \mathrm{~A}$ \\
\hline Temperate needle broad-leaved mixed forests & 84 & $20.5 \pm 29.6 \mathrm{~B}$ & $12.7 \pm 38.1 \mathrm{~A}$ & $15.6 \pm 33.4 \mathrm{~B}$ & $5.37 \pm 3.57 \mathrm{AB}$ & $5.43 \pm 3.99 \mathrm{~B}$ & $10.8 \pm 6.75 \mathrm{~B}$ \\
\hline Warm temperate deciduous broad-leaved forests & 102 & $20.4 \pm 20.8 B$ & $7.44 \pm 9.43 \mathrm{~A}$ & $12.2 \pm 11.7 \mathrm{~B}$ & $5.24 \pm 6.18 \mathrm{AB}$ & $4.70 \pm 6.27 \mathrm{~B}$ & $9.95 \pm 9.11 \mathrm{~B}$ \\
\hline Subtropical evergreen broad-leaved forests & 72 & $31.2 \pm 30.8 \mathrm{~B}$ & $17.1 \pm 17.6 \mathrm{~A}$ & $21.1 \pm 21.5 \mathrm{AB}$ & $5.21 \pm 4.0 \mathrm{AB}$ & $8.27 \pm 8.8 \mathrm{AB}$ & $13.5 \pm 11.7 \mathrm{~B}$ \\
\hline Tropical monsoon forests & 54 & $23.1 \pm 12.2 B$ & $14.9 \pm 7.54 \mathrm{~A}$ & $16.9 \pm 8.32 \mathrm{AB}$ & $4.59 \pm 3.91 \mathrm{~B}$ & $8.47 \pm 5.92 \mathrm{AB}$ & $13.1 \pm 7.78 \mathrm{~B}$ \\
\hline
\end{tabular}

$25.6 \mathrm{~kg} \mathrm{C} \mathrm{m}^{-2}$ in the mineral horizon. The floodplain forest soils' carbon density was lowest, and the highest was observed in the volcanic soils.

\subsection{Relationship between SOC density and environmental factors}

There were positive correlations between SOC density and latitude, elevation, MAP, nitrogen, silt content and clay content and negative correlations between SOC density and longitude, MAT, pH, bulk density, and sand content. Significant correlations were observed between SOC density and nitrogen, and bulk density and soil texture (Table 6). Strong relationships were found between the SOC density and MAT and MAP in the organic horizon. The correlation coefficients between the SOC density of the organic horizon and the climate-related factors were higher than those of the mineral horizon.

Table 5 SOC content and density for the 22 Genetic Soil Classification of China soil groups in east China

\begin{tabular}{|c|c|c|c|c|c|c|c|c|}
\hline \multirow{2}{*}{$\begin{array}{l}\text { Soil groups in Genetic Soil } \\
\text { Classification of China }\end{array}$} & \multirow{2}{*}{$\begin{array}{l}\text { Soil groups in Chinese } \\
\text { soil taxonomy }\end{array}$} & \multirow{2}{*}{$\begin{array}{l}\text { Number of } \\
\text { profiles }\end{array}$} & \multicolumn{3}{|c|}{ SOC content $\left(\mathrm{g} \mathrm{C} \mathrm{kg}^{-1}\right)$} & \multicolumn{3}{|c|}{ SOC density $\left(\mathrm{kg} \mathrm{C} \mathrm{m}^{-2}\right)$} \\
\hline & & & $\begin{array}{l}\text { Organic } \\
\text { horizon }\end{array}$ & $\begin{array}{l}\text { Mineral } \\
\text { horizon }\end{array}$ & Profile & $\begin{array}{l}\text { Organic } \\
\text { horizon }\end{array}$ & $\begin{array}{l}\text { Mineral } \\
\text { horizon }\end{array}$ & Profile \\
\hline Brown coniferous forest soils & Umb-Cryic Cambisols & 24 & $106 \pm 56.4$ & $10.8 \pm 9.11$ & $27.2 \pm 14.0$ & $8.01 \pm 4.78$ & $13.8 \pm 11.5$ & $21.8 \pm 15.3$ \\
\hline Bleach Spodosol & Umb-Cryic Cambisols & 6 & $95.7 \pm 8.89$ & $5.49 \pm 0.22$ & $24.3 \pm 15.5$ & $13.7 \pm 11.1$ & $6.43 \pm 0.84$ & $20.1 \pm 10.3$ \\
\hline Floodplain forest soils & Dark-Aquic Cambosols & 3 & $3.40 \pm 1.13$ & $0.71 \pm 0.23$ & $1.17 \pm 0.47$ & $0.49 \pm 0.16$ & $0.94 \pm 0.37$ & $1.43 \pm 0.53$ \\
\hline Peat soils & Fibri-Permagelic Histosols & 6 & $171 \pm 31.1$ & $186 \pm 21.6$ & $180 \pm 4.07$ & $4.10 \pm 0.55$ & $12.8 \pm 0.59$ & $16.9 \pm 1.14$ \\
\hline Dark-brown earths & $\begin{array}{l}\text { Dark-Aquic Cambosols/Bori-Udic } \\
\text { Cambosols/Mollic Boric Luvisols }\end{array}$ & 87 & $26.5 \pm 18.9$ & $8.55 \pm 8.13$ & $13.1 \pm 9.56$ & $6.31 \pm 3.83$ & $6.63 \pm 5.87$ & $12.9 \pm 8.26$ \\
\hline Albic soil & Albic-Boric Luvisols & 12 & $30.9 \pm 25.9$ & $2.24 \pm 1.33$ & $6.85 \pm 4.16$ & $4.70 \pm 2.58$ & $2.49 \pm 1.61$ & $7.19 \pm 3.89$ \\
\hline Cinnamon soils & $\begin{array}{l}\text { Hapli-Ustic Luvisols/Hapli-Ustic } \\
\text { Cambosols }\end{array}$ & 36 & $10.3 \pm 9.21$ & $5.48 \pm 3.46$ & $6.80 \pm 4.19$ & $2.56 \pm 1.65$ & $3.52 \pm 4.57$ & $6.08 \pm 4.46$ \\
\hline Moisture soils & Ochri-Aquic Cambosols & 12 & $8.23 \pm 6.07$ & $6.88 \pm 6.14$ & $4.98 \pm 2.68$ & $2.69 \pm 2.67$ & $3.71 \pm 1.16$ & $6.51 \pm 3.41$ \\
\hline Brown earths & Hapli-Udic Luvisols & 27 & $40.9 \pm 25.1$ & $6.86 \pm 7.38$ & $23.7 \pm 13.6$ & $10.4 \pm 8.89$ & $4.67 \pm 5.32$ & $15.0 \pm 9.36$ \\
\hline Coastal solonchaks & Aqui-Orthic Halosols & 6 & $8.46 \pm 5.06$ & $5.36 \pm 3.82$ & $2.70 \pm 0.26$ & $1.18 \pm 0.38$ & $2.54 \pm 0.65$ & $3.71 \pm 0.26$ \\
\hline Chestnut soils & Calci-Ustic Lsohumosols & 3 & $3.35 \pm 0.98$ & $11.6 \pm 3.40$ & $1.62 \pm 0.48$ & $0.96 \pm 0.28$ & $1.56 \pm 0.74$ & $2.53 \pm 0.46$ \\
\hline Skeletal soil & Lit-Ust-Alluvic Entisols & 3 & $1.89 \pm 0.31$ & $1.57 \pm 0.51$ & $1.76 \pm 0.57$ & $1.92 \pm 0.62$ & $1.27 \pm 0.41$ & $3.19 \pm 1.03$ \\
\hline Lime concretion black soils & Shajiang Calci-Aquic Vertosols & 6 & $6.92 \pm 1.69$ & $3.04 \pm 1.56$ & $5.08 \pm 0.59$ & $3.07 \pm 0.91$ & $2.98 \pm 0.43$ & $6.05 \pm 0.47$ \\
\hline Yellow-cinnamon soils & Hap-Ustic Luvisols & 3 & $5.88 \pm 1.45$ & $4.59 \pm 1.61$ & $4.89 \pm 1.29$ & $1.87 \pm 0.49$ & $5.43 \pm 0.93$ & $7.30 \pm 1.62$ \\
\hline Red earths & $\begin{array}{l}\text { Rhodi-Udic Ferralsols/Ferri-Udic } \\
\text { Cambosols/Ali-Perudic Cambosols }\end{array}$ & 39 & $13.5 \pm 9.13$ & $5.49 \pm 5.05$ & $7.15 \pm 5.13$ & $2.91 \pm 1.43$ & $5.91 \pm 5.86$ & $8.82 \pm 6.65$ \\
\hline Yellow earths & $\begin{array}{l}\text { Hapli-Udic Ferralsols/Hap-Udic } \\
\text { Luvisols }\end{array}$ & 9 & $36.4 \pm 26.8$ & $8.91 \pm 7.44$ & $13.4 \pm 15.4$ & $4.01 \pm 2.67$ & $6.82 \pm 6.97$ & $10.8 \pm 9.44$ \\
\hline Yellow-brown soil & Hap-Udic Luvisols & 6 & $9.10 \pm 4.82$ & $3.83 \pm 1.77$ & $5.00 \pm 2.25$ & $2.53 \pm 0.93$ & $4.18 \pm 2.06$ & $6.71 \pm 2.99$ \\
\hline Lateritic red earths & Ferric-Udic Cambisols & 30 & $29.8 \pm 18.8$ & $13.2 \pm 9.69$ & $17.9 \pm 14.7$ & $6.21 \pm 4.71$ & $10.3 \pm 6.74$ & $16.5 \pm 8.40$ \\
\hline Latosols & $\begin{array}{l}\text { Rhodi-Udic Ferralsols/Hap-Udic } \\
\text { Ferrisols }\end{array}$ & 12 & $22.1 \pm 15.9$ & $15.5 \pm 10.2$ & $17.7 \pm 12.6$ & $3.86 \pm 3.02$ & $6.41 \pm 3.35$ & $10.3 \pm 4.15$ \\
\hline Limestone soils & $\begin{array}{l}\text { Black-Lithomorphic Isohumosols/Calci- } \\
\text { Udic Ferrisols }\end{array}$ & 6 & $72.9 \pm 12.4$ & $34.3 \pm 3.85$ & $49.0 \pm 10.1$ & $12.8 \pm 2.87$ & $20.3 \pm 3.88$ & $33.1 \pm 6.76$ \\
\hline Volcanic soils & Hapli-Udic Andosols & 6 & $75.0 \pm 12.7$ & $50.4 \pm 18.0$ & $55.7 \pm 16.9$ & $9.42 \pm 0.62$ & $25.6 \pm 2.87$ & $35.0 \pm 2.26$ \\
\hline Purplish soils & Purpli-Udic Cambosols & 6 & $16.4 \pm 6.25$ & $6.38 \pm 1.15$ & $11.2 \pm 2.78$ & $4.47 \pm 1.96$ & $2.42 \pm 0.61$ & $6.89 \pm 2.57$ \\
\hline
\end{tabular}


Table 6 Relationships between SOC density and environmental factors in east China

\begin{tabular}{llllllllllll}
\hline Soil layer & Longitude & Latitude & Elevation & MAT & MAP & Nitrogen & pH & Bulk density & Sand content & Silt content & Clay content \\
\hline Organic horizon & -0.065 & $0.285^{* *}$ & 0.122 & $-0.32^{* *}$ & $0.207^{*}$ & $0.443^{* *}$ & -0.05 & $-0.331^{* *}$ & -0.072 & 0.071 \\
Mineral horizon & $-0.263^{*}$ & 0.003 & 0.153 & -0.049 & 0.003 & $0.392^{* *}$ & -0.005 & $-0.264^{* *}$ & $-0.167^{* *}$ & 0.078 & 0.041 \\
Profile & $-0.223^{*}$ & 0.051 & 0.172 & -0.104 & 0.038 & $0.426^{* *}$ & -0.015 & $-0.299^{* *}$ & $-0.101^{*}$ & 0.075 & 0.075 \\
\hline
\end{tabular}

$* P<0.05 ; * * P<0.01$

\section{Discussion}

\subsection{Distribution of SOC}

Organic matter input, output, spatial location, and related soil properties and processes all help to determine the spatial variability of the SOC content (Jenny 1941; Schlesinger 1977; Liu et al. 2011). This study showed that SOC content decreased with increasing soil depth and the sharp decrease occurred from the surface to depths of $20-30 \mathrm{~cm}$. Organic inputs into the soil occur mainly in the surface horizons and decrease sharply with depth. However, little variation occurred at depths below $60 \mathrm{~cm}$ (Fig. 2), possibly because the SOC content is primarily determined by the distribution of the root system in deep soil (Zhou et al. 2013; Jobba'gy and Jackson 2000). Moreover, decomposition weakens with increasing soil depth, which means that decomposition proceeds more slowly in plant debris located deep in the soil. Other studies have reported similar findings (Han et al. 2010; Li et al. 2013).

China's forests are mainly distributed in mountainous areas and hilly regions. Forest SOC density was characterized by high spatial variability in east China, due to the differences in climate, vegetation, and topography in mountains (Zhu et al. 2010; Yoo et al. 2006). We found that the forest SOC density for the entire soil profile was comparatively higher in north-eastern China and southeastern China, and lower in middle-eastern China. In north-eastern China, lower temperatures could slow down the decomposition of SOC and soil respiration, allowing SOC to accumulate (Rozhkov et al. 1996; Xie et al. 2008). In addition, SOC density under natural forest was significantly higher than that in the plantation (Yang et al. 2009; Wang et al. 2014). Natural forest is mainly distributed in north-eastern and south-eastern China, with the forest area coverage of natural forest above 77.0, 32.1, and $51.3 \%$, respectively, in north-eastern, middle-eastern, and south-eastern China (The State Forest Bureau 2014). The lowest SOC density could be attributed to the large proportion of plantation and human activities in middle-eastern China (Xie 2004).

In order to further understand the distribution patterns of SOC density in east China, we investigated the relationships between SOC density and forest types. The results showed that the distribution pattern of forest SOC density based on forest types is similar to geographical regions. Li (2008) indicated a close relationship between the geographical distribution of vegetation and climate zone distribution and concluded that the spatial distribution characteristic of SOC density is characterized by an obvious zonality. SOC density was highest in the cold-temperate coniferous forest, mainly because of low decomposition rates of soil organic matter in the cold-temperate climate (Xie et al. 2008). In the warm temperate deciduous broad-leaved forest, SOC density was lowest because of high rates of decomposition (Li et al. 2004), especially the large area of plantation (The State Forest Bureau 2014).

We also studied soil types, especially the main zonal soils (brown coniferous forest soils, dark-brown earths, brown earths, yellow-cinnamon soils, yellow-brown earths, yellow earths, red earths, latosolic red earths, and latosols), to understand the distribution patterns of SOC density in east China. The results showed that generally SOC density decreased from north to south in east China, consistent with other reports (Wang et al. 2001; Wu et al. 2003; Zhou et al. 2003). The SOC in the main soil types was characterized by high spatial variability. Soil types changed from dark-brown earths to brown earths, to yellow-cinnamon soils, to yellow-brown earths, to yellow earths, to red earths, to latosolic red earths, and to latosols, respectively, along with temperature change from north to south (Wang et al. 2001). Therefore, the spatial distribution of the soil types responded to these climatic zones, large terrain features, and major biodiversity patterns, showing a general increasing trend of SOC density with increasing latitude in east China.

\subsection{Influencing factors on SOC}

Our data indicated that SOC density increased as the precipitation increased and decreased as the temperature increased. The findings were consistent with those of other studies (Wang et al. 2002, 2004; Yang et al. 2007). SOC accumulation was controlled by the rates of biomass accumulation and decomposition (Lal et al. 1995). Climate affects microbial decomposition and transformation of organic matter by influencing soil temperature, moisture, ventilation, etc. On the other hand, climate also affects vegetation growth and the subsequent litter inputs of carbon to the soil. Therefore, soil 
carbon stocks are highest in cool and moist biomes and lowest in hot and dry biomes (Davidson et al. 2000). Our study found that the SOC density of the organic horizon was significantly affected by temperature and precipitation, due to the litter decomposition occurring in soil surface.

The general trend of the temperature decreased from south to north and precipitation decreased from east to west in east China. SOC density increased as the latitude increased, particularly in the organic horizon. The temperature decreases with increases in latitude, and the slower activity of soil microbes leads to the decrease of the mineralization rate of soil organic matter (Zhu et al. 2010). The density of SOC showed a significant negative correlation with the longitude and a positive correlation with the elevation, mainly because the natural coniferous forest is extensively distributed in low longitude and high elevation area. In addition, human disturbance would be limited by the lower population density in the mountains. However, sometimes, the change of SOC density was not necessarily responding to longitude and latitude because climate also affected by altitude and topography (Li 2008). Longitude, latitude, and elevation are fixed parameters that are not affected by other factors. Position-related factors can only reflect the status of heat and water but not the actual situation (Lv et al. 2010).

We found significant relationships between SOC density and nitrogen, bulk density, and soil texture (Table 6), which was consistent with other findings (Fu et al. 2010; Lei et al. 2013; Yang et al. 2008). In this study, we found SOC density was significantly correlated with soil texture in the mineral horizon. These results are similar to those reported by Jobba'gy and Jackson (2000). Some research studies (Zhou et al. 2013; Zhou 2013) suggested that carbon characteristics and stability mechanisms may be different between topsoil and deep soil, and their carbon dynamic process and the response of the external environment change could be different too. The SOC in the soil surface were mainly affected and predicted by precipitation and temperature, while in deeper layers, clay content was the best predictor (Jobba'gy and Jackson 2000).

\subsection{Comparisons with earlier estimates}

We compared the estimates of China's forest SOC density with other estimates of SOC density and found it varied widely from one study to another for several reasons (Table 7). For example, each study acquired data from a variety of data sources and used different calculation methods in different areas and studies. In addition, a complete set of inventory data does not exist and measurements of SOC contain inherent spatial variability. Most of these reports used China's first and/or second soil survey data. For example, using the second national soil survey data, Wang et al. (2004) demonstrated that the average SOC density in China's forest could be estimated to be $13.2 \mathrm{~kg} \mathrm{C} \mathrm{m}^{-2}$; Xie (2004) estimated the average SOC density of forests of $11.6 \mathrm{~kg} \mathrm{C} \mathrm{m}^{-2}$. Using the same data from the second national soil survey combined with field observations in China, Yang et al. (2007) estimated the average SOC density of forests to be $10.5 \mathrm{~kg} \mathrm{C} \mathrm{m}^{-2}$. Our estimates of SOC density was close to the results of $\mathrm{Li}$ (2008) because the forest profile data used in their calculation of nationwide forest SOC density were also mostly from the east of China, with very few from the northwest and west of China. However, using the data from existing literature and monographs, Zhou et al. (2000) estimated the average forest SOC density was $19.36 \mathrm{~kg} \mathrm{C} \mathrm{m}^{-2}$ higher than Li (2008), mainly because different vegetation and soil classification systems, various data sources, and different calculation methods were used in their studies. Based on the field measurements, Li et al. (2004) found that forest SOC density was relatively higher (19.1 $\mathrm{kg} \mathrm{C} \mathrm{m}^{-2}$ ) using the Carbon Exchange in the Vegetation-Soil-Atmosphere (CEVSA) model.

The sampling methods, location and season of sampling, the land-cover classification system, and land-use change are the main sources of uncertainty in SOC density estimates. Soil carbon content is not likely to be uniform for a given region. In this study, the measured soil depth was used to calculate the SOC density. However, the international calculation method of measuring SOC reservoirs is typically based on organic content in the top $1 \mathrm{~m}$ of soil (Sombroek et al. 1993; Wang

Table 7 Comparisons of estimated forest SOC density with other studies

\begin{tabular}{|c|c|c|c|c|}
\hline Reference & Data source & SOC density valuation & $\begin{array}{l}\text { Soil depth } \\
\text { (m) }\end{array}$ & $\begin{array}{l}\text { SOC density } \\
\left.(\mathrm{kg} \mathrm{C} \mathrm{m})^{-2}\right)\end{array}$ \\
\hline Wang et al. 2004 & China's second national soil survey & Weighted mean value by area & 1.0 & 13.2 \\
\hline Xie 2004 & China's second national soil survey & Weighted mean value by area & 1.0 & 11.6 \\
\hline Yang et al. 2007 & China's second national soil survey and field measurement & Weighted mean value by area & 1.0 & 10.0 \\
\hline Li 2008 & Literature and monographs & Weighted mean value by area & 0.6 & 12.3 \\
\hline Zhou et al. 2000 & Literature and monographs & Weighted mean value by area & Actual depth & 19.4 \\
\hline Li et al. 2004 & Meteorological data and atmospheric $\mathrm{CO}_{2}$ & CEVSA model & 1.0 & 19.1 \\
\hline This study & Field measurement & Calculated profile values & Actual depth & 12.4 \\
\hline
\end{tabular}


et al. 2004; Yang et al. 2007). This variation in methods could result in different findings. We expect our estimates to provide a large amount of detailed and reliable experimental data in carbon content and density in Chinese forest soils, although large uncertainties in estimates of forest SOC still exist obviously. More accurate carbon estimates could be improved by use of a large number of sampled forests, as well as by accounting for variations in soil type, soil depth, soil horizon, and their corresponding SOC content.

\section{Conclusions}

In east China, the forest SOC content and density were $17.5 \mathrm{~g} \mathrm{C} \mathrm{kg}^{-1}$ and $12.4 \mathrm{~kg} \mathrm{C} \mathrm{m}^{-2}$, respectively. The average SOC densities in the organic horizon and mineral horizon were 5.47 and $6.91 \mathrm{~kg} \mathrm{C} \mathrm{m}^{-2}$, respectively. The average SOC density in the organic horizon accounted for $44.2 \%$ of the total organic carbon density. The average forest SOC density in north-eastern China and south-eastern China was higher than that of middle-eastern China. SOC density was characterized by high spatial variability in different soil types ranged from 1.43 to $35.0 \mathrm{~kg} \mathrm{C} \mathrm{m}^{-2}$. The responses of SOC density to environmental factor variables differed among different soil horizons. The importance of influencing controls switched with depth, precipitation, and temperature dominating in the organic horizon and soil texture dominating in the mineral horizon.

Acknowledgments We thank Professor Xiaoyang Cui, Qiwu Sun, Jinglin Chen, Qingchao Geng, and Huirong Hu for assistance in field investigation and soil sample collection. We appreciate Professor Scott Chang for critically revising the manuscript and offering valuable comments.

\section{Compliance with ethical standards}

Funding This study was supported by the Specific Basic Research Program of the Ministry of Sciences and Technology of China (2014FY120700).

\section{References}

Batjes NH (1996) Total carbon and nitrogen in the soils of the world. Eur J Soil Sci 47:151-163. doi:10.1111/ejss.12114_1

Bohn HL (1982) Estimate of organic carbon in world soils: II. Soil Sci Soc Am J 46:1118-1119. doi:10.2136/sssaj1982.03615995004600050050x

China Meteorological Administration. China meteorological data sharing service system. Available at: http://cdc.cma.gov.cn/

Chinese Ministry of Forestry (2009) Forest resource statistics of China (2004-2008) Department of Forest Resource and Management. Chinese Ministry of Forestry, Beijing

Chinese National Investigation Office (1993-1996) Chinese soil. Beijing, Chinese Agricultural Press
Chinese Soil General Survey Office (1993) Chinese soil classification system. Agriculture Press, Beijing

Chinese Soil Taxonomy Research Group, Institute of Soil Science, Chinese Academy of Sciences, Cooperative Research Group on Chinese Soil Taxonomy (2001) Keys to Chinese soil taxonomy, 3rd edn. University of Science and Technology of China Press, Hefei, In Chinese

Dai EF, Zhai RX, Ge QS, Wu XQ (2014) Detecting the storage and change on topsoil organic carbon in grasslands of Inner Mongolia from 1980s to 2010s. J Geogr Sci 24:1035-1046. doi:10.1007/ s11442-014-1136-9

Davidson EA, Trumbore SE, Amundson R (2000) Soil warming and organic carbon content. Nature 408:789-790. doi:10.1038/ 35048672

Eswaran H, Van DBE, Reich P (1993) Organic carbon in soils of the world. Soil Sci Soc Am J 57:192-194. doi:10.2136/sssaj1993. 03615995005700010034x

Fu XL, Shao MA, Wei XR, Horton R (2010) Soil organic carbon and total nitrogen as affected by vegetation types in Northern Loess Plateau of China. Geoderma 155:31-35. doi:10.1016/j.geoderma.2009.11.020

Han FP, Hu W, Zheng WP, Du F, Zhang XC (2010) Estimating soil organic carbon storage and distribution in a catchment of Loess Plateau, China. Geoderma 154:261-266. doi:10.1016/j.geoderma. 2009.10.011

Hou XY (1983) Vegetation of China with reference to its geographical distribution. Ann Mo Bot Gard 70:508-548. doi:10.2307/2992085

Huang ZL, Tian YW, Xiao WF, Ma DJ (2013) Soil organic carbon sequestration in protection forest in Three Gorges reservoir area. J Nanjing Forest Univ (Nat Sci Edit) 37:15-20, In Chinese with English abstract

International Soil Reference and Information Center, van Reeuwijk LP (eds) (1995) Procedures for soil analysis. ISRCI, Wageningen

Jenny H (1941) Factors of soil formation, a system of quantitative pedology. McGraw-Hill, New York

Jin F, Yang H, Cai ZC, Zhao QG (2001) Calculation of density and reserve of organic carbon in soils. Acta Pedol Sin 38:522-528, In Chinese with English abstract

Jobba'gy EG, Jackson RB (2000) The vertical distribution of soil organic carbon and its relation to climate and vegetation. Ecol Appl 10:423436. doi: $10.2307 / 2641104$

Kern JS (1994) Spatial patterns of soil organic carbon in the contiguous United States. Soil Sci Soc Am J 58:439-455. doi:10.2136/ sssaj1994.03615995005800020029x

Lal R, Kimble J, Levine E, Whitman C (1995) World soils and greenhouse effect: an overview. In: Lal R, Kimble J, Levine E, Stewart BA (eds) Soils and global change. CRC Lewis Publishers, Boca Raton, pp 1-7, Chap. 1

Lei D, ShangGuan ZP, Sweeney S (2013) Changes in soil carbon and nitrogen following land abandonment of farmland on the Loess Plateau, China. PLoS ONE 8:e71923. doi:10.1371/journal.pone. 0071923

Li J (2008) Study on soil carbon stock and its spatial distribution, influence factors in the forest of China. Sichuan Agr Univ (in Chinese with English abstract)

Li KR, Wang SQ, Cao MK (2004) Vegetation and soil carbon storage in China. Sci China Ser D 47:49-57

Li MM, Zhang XC, Pang GW, Han FP (2013) The estimation of soil organic carbon distribution and storage in a small catchment area of the Loess Plateau. Catena 101:11-16. doi:10.1016/j.catena.2012. 09.012

Liu SR, Wang H, Luan JW (2011) A review of research progress and future prospective of forest soil carbon stock and soil carbon process in China. Acta Ecol Sin 31:5437-5448, In Chinese with English abstract

Liu Y, Zha TG, Fu RJ (2012) Soil organic carbon storage and vertical distribution of different forest types in Baihua Mountain area. Acta 
Agr Boreali Occidentalis Sin 21:182-187, In Chinese with English abstract

Lv GH, Wang XY, Zhang YS, Jia QY, Xie YB (2010) Soil carbon, nitrogen of farmland and their relationships with climatic factors. J Agro Environ Sci 29:1612-1617, In Chinese with English abstract

Malhi Y, Baldocchi DD, Jarvis PG (1999) The carbon balance of tropical, temperate and boreal forests. Plant Cell Environ 22:715-740. doi: 10.1046/j.1365-3040.1999.00453.x

National Soil Survey Office (1998) Soils of China. Chinese Agricultural Press, Beijing, In Chinese

Nelson DM, Sommer LE (1975) A rapid and accurate method for estimating organic carbon in soil. Proc Indiana Acad Sci 84:456-462

Parkinson JA, Allen SE (1975) A wet oxidation procedure suitable for the determination of nitrogen and mineral nutrients in biological material. Commun Soil Sci Plant 6:1-11. doi:10.1080/ 00103627509366539

Post WM, Pastor J, Zinke PJ, Stangenberger AG (1985) Global patterns of soil nitrogen storage. Nature 317:613-616. doi:10.1038/ $317613 \mathrm{a} 0$

Post WM, Peng TH, Emanuel WR, King AW, DeAngelis DL (1990) The global carbon cycle. Am Sci 78:310-326

Pregitzer KS, Euskirchen ES (2004) Carbon cycling and storage in world forests: biome patterns related to forest age. Glob Chang Biol 10: 2052-2077. doi:10.1111/j.1365-2486.2004.00866.x

Rozhkov VA, Wagner VB, Kogut BM, Konyushkov DE, Nilsson S, Sheremet BV, Shvidenko AZ (1996) Soil carbon estimates and soil carbon map for Russia. IIASA work paper, WR96-60

Schlesinger WH (1977) Carbon balance in terrestrial detritus. Annu Rev Ecol Syst 8:51-81. doi:10.1146/annurev.es.08.110177.000411

Sedjo RA (1993) The carbon cycle and global forest ecosystem. Water Air Soil Pollut 70:295-307. doi:10.1007/BF01105003

Sombroek WG, Nachtergaele FO, Hebel A (1993) Amount, dynamics and sequestering of carbon in tropical and subtropical soils. Ambio 22:417-426

The State Forestry Bureau (2014) The eighth of national continuous forest resources inventory. The State Forestry Bureau, Beijing

Wang DP, Wang WB, Zheng L, Luo XH, Zou BX, Zhang YF, Wu XP (2014) Compared of soil organic carbon of different plantations in China. Ecol Environ Sci 23:698-704 ,In Chinese with English abstract

Wang SQ, Zhou CH, Li KR, Zhu SL, Huang FH (2001) Estimation of soil organic carbon reservoir in China. J Geogr Sci 11:1-11. doi:10. 1007/BF02837371

Wang SP, Zhou GS, Lu YC, Zhou JJ (2002) Distribution of soil carbon, nitrogen and phosphorus along Northeast China Transect (NECT) and their relationship with climatic factors. Acta Phytoecol Sin 26: 513-517, In Chinese with English abstract

Wang SQ, Huang M, Shao XM, Robert A, Li KR, Ji JJ (2004) Vertical distribution of soil organic carbon in China. Environ Manag 33: 200-209. doi:10.1007/s00267-003-9130-5
Winjum JK, Schroeder PE (1997) Forest plantations of the world: their extent, ecological attributes, and carbon storage. Agric For Meteorol 84:153-167. doi:10.1016/S0168-1923(96)02383-0

Wu HB, Guo ZT, Peng CH (2003) Distribution and storage of soil organic carbon in China. Glob Biogeochem Cycles 17:1048-1058. doi:10. 1029/2001GB001844

Xie XL (2004) Study on soil organic carbon stocks in national and regional scale using GIS. Nanjing Normal Univ (in Chinese with English abstract)

Xie HT, Li WF, Bai Z, He HB, Zhang XD (2008) Distribution of amino sugars in forest soil profiles of the Changbai Mountain. J Grad Sch Chin Acad Sci 25:657-664

Yang YH, Mohammat A, Zhou R, Feng JM (2007) Storage, patterns and environmental controls of soil organic carbon in China. Biogeochemistry 84:131-141. doi:10.1007/s10533-007-9109-Z

Yang YH, Fang JY, Tang YH, Ji CJ, Zhang CY, He JS, Zhu B (2008) Storage, patterns and controls of soil organic carbon in the Tibetan grasslands. Glob Chang Biol 14:1592-1599. doi:10.1111/j.13652486.2008.01591.x

Yang YS, Guo JF, Chen GH, Yin YF, Gao R, Lin CF (2009) Effects of forest conversion on soil labile organic carbon fractions and aggregate stability in subtropical China. Plant Soil 323:153-162. doi:10. 1007/s11104-009-9921-4

Yang HF, Mu SJ, Sun CM, Li JL, Ju WM (2011) Summary of research on estimation of organic carbon storage in grassland ecosystem. Chin J Grassl 33:107-114, In Chinese with English abstract

Yoo K, Armundson R, Heimsath AM, Dietrich WE (2006) Spatial patterns of soil organic carbon on hill slopes: integrating geomorphic processes and the biological C cycle. Geoderma 130:47-65. doi:10. 1016/j.geoderma.2005.01.008

Zhang WR (1986) Chinese forest soil. Science press, Beijing, In Chinese

Zhang M, Zhang XK, Liang WJ (2011) Distribution of soil organic carbon fractions along the altitudinal gradient in Changbai Mountain, China. Pedosphere 21:615-620

Zhou YX (2013) The effect of different regeneration forest on deep soil organic carbon in the mid-subtropical zone. Fujian Normal Univ (in Chinese with English abstract)

Zhou YR, Yu ZL, Zhao ST (2000) Carbon storage and budget of major Chinese forest types. Acta Phytoecol Sin 24:518-522, In Chinese with English abstract

Zhou CH, Zhou QM, Wang SQ (2003) Estimating and analyzing the spatial distribution of soil organic carbon in China. Ambio 32:612. doi:10.1639/0044-7447(2003)032[0006:EAATSD]2.0.CO;2

Zhou YX, Lv SM, Xie JS, Yang ZJ, Jang J, Yang YS (2013) Sources, characteristics and stability of organic carbon in deep soil. J Subtrop Resour Environ 8:48-55, In Chinese with English abstract

Zhu B, Wang XP, Fang JY, Piao SL, Shen HH, Zhao SQ, Peng CH (2010) Altitudinal changes in carbon storage of temperate forests on $\mathrm{Mt}$ Changbai, Northeast China. J Plant Res 123:439-452. doi:10. 1007/s10265-009-0301-1 